\title{
Rola rodziny w kształtowaniu patriotycznych postaw
}

Jakkolwiek jednostka jest sama w sobie jednością, to studiujący ją uczeni wyróżniają w niej różne wymiary: cielesny, psychiczny czy duchowy. Nie negując istnienia takich wymiarów, socjologowie koncentrują się na społecznym wymiarze jednostki, który kształtuje się w procesie socjalizacji.

Jednostka, rodząc się, nie ma zakodowanego żadnego wzoru kulturowego, właściwego konkretnej rasie czy płci. Ten wzór jednostka zdobywa w procesie socjalizacji. Cielesność i płeć predestynują jednostkę do określonych funkcji w procesie prokreacji czy nawet socjalizacji, ale przez samo urodzenie nie sytuują jej w określonym wzorze kulturowym. Ten ostatni stanie się jej udziałem przez fakt uczestnictwa w procesie socjalizacji, któremu będzie poddana w ramach oddziaływania na nią agend socjalizujących: rodziny, grup koleżeńskich, szkoły, mass mediów...

Chociaż sam proces socjalizacji można traktować jako kontinuum, to różne agendy socjalizujące różnią się między sobą co do przekazywanych treści, okoliczności, w jakich socjalizacja ma miejsce, sposobów ich przekazywania... Wręcz może się zdarzyć, że przekazywane treści kolidują ze sobą, tworząc inny wzór osobowości. Powszechnie przyjmuje się na przykład, że grupy koleżeńskie w przeciwieństwie do rodziny prezentują bardziej nowoczesne wzory i wartości czy proponują egalitarne interakcje... 
Proces socjalizacji umożliwia jednostce życie w określonym społeczeństwie, wyposażając ją w to wszystko, co pozwoli jej w nim funkcjonować. Bardziej konkretnie jednostka uczy się pełnienia ról, nabywa wielorakich umiejętności, przyjmuje system wartości swego środowiska, kształtuje aspiracje i uczy się sposobów ich realizacji. Oznacza to, że w procesie socjalizacji jednostka staje się istotą społeczną - nabywa wzorów kulturowych określonego społeczeństwa, staje się jego członkiem.

Ważnym elementem wzorów kulturowych jest świat wartości ${ }^{1}$. Cechą wartości jest to, „że swym sensem w chwili ich postrzegania wytrącają nas z obojętności, budzą w nas różne emocjonalne poruszenia wstępne, które następnie przeradzają się we właściwe odpowiedzi"2. Tym sposobem wartości stają się źródłem postaw, rozumianych jako stałe sposoby reagowania na określone bodźce. Mając to na uwadze, należy stwierdzić, że przekazywanie wzorów kulturowych w ramach socjalizacji jest zwyczajnie procesem internalizacji określonych wartości ${ }^{3}$.

Powszechnie przyjmuje się, że wśród agend socjalizujących rodzina jest najważniejszą. Wynika to z faktu, że - jak stwierdza Sobór Watykański II w deklaracji Gravissimum educationis - „rodzina jest pierwszą szkołą cnót społecznych, potrzebnych wszelkim społecznościom” (GE 3). Charakter i funkcjonowanie rodziny stanowią bowiem najbardziej odpowiednie środowisko praktyki cnót, kształtowania postaw i wartości, które ze swej natury warunkują funkcjonowanie społeczności. Patriotyzm jest jedną z nich. Trudno sobie wyobrazić trwanie na dłuższą metę jakiegokolwiek społeczeństwa, w którym znaczna jego część prezentowałaby obojętne postawy wobec własnej ojczyzny.

\section{Proces socjalizacji dzieci}

Jednym z warunków przetrwania jakiegokolwiek społeczeństwa jest przekazywanie nowemu pokoleniu własnej kultury: języka, zwyczajów, norm, praw, obyczajów... Kulturowa przynależność bowiem z jednej strony sytu-

Wartością dla określonego podmiotu jest wszystko to, co ten podmiot uważa za cenne. Świat wartości jest bardzo szeroki. Stąd wartości częściej niż pojedynczo występują w pewnym układzie - tworzą system.

2 A. Siemianowski, Człowiek a świat wartości, Warszawa 1993, s. 29.

3 W. Cichoń, Wartości, człowiek, wychowanie, Kraków 1996, s. 119. 
uje jednostkę w określonym kręgu kulturowym, a z drugiej to w kolejnym pokoleniu kultura może przetrwać. Oznacza to, że gdyby przekaz kulturowy nie miał miejsca, społeczeństwo przestałoby istnieć wraz ze śmiercią ostatniego jej przedstawiciela. Zwrócił na ten fakt uwagę Émile Durkheim: „...życie społeczne [...] zamyka się w pewnym kręgu. Z jednej strony od społeczeństwa jednostka otrzymuje to, co w niej najlepsze [...] - kulturę umysłową i moralną. [...] Ale jednocześnie społeczeństwo istnieje i żyje jedynie w jednostkach i przez jednostki. Gdyby idea społeczeństwa wygasła w umysłach poszczególnych ludzi, gdyby zwykli ludzie przestali wspólnie wyznawać wierzenia i tradycje, podzielać zbiorowe dążenia, wówczas by umarło społeczeństwo"4.

\subsection{Rodzina podstawową agendą socjalizującą}

Chociaż kultura jest przekazywana nowemu pokoleniu przez różne agendy socjalizujące, to najważniejszą z nich jest rodzina. Za taką pozycją rodziny w procesie socjalizacji przemawiają dwa argumenty. Najpierw rodzina jest chronologicznie pierwszą agendą, a po wtóre obejmuje najważniejsze obszary życia kulturowego. W odniesieniu do pierwszej cechy rodzina nie natrafia na żadną inną formę socjalizacji, ponieważ na tym etapie jednostka (niemowlę), a następnie dziecko otrzymuje przekaz kulturowy jedynie od rodziny. Rzecz bowiem w tym, że żadna inna agenda socjalizująca nie ma dostępu do formacji kulturowej dziecka. Druga cecha podkreśla fakt, że treści socjalizacyjne na tym etapie są ze wszech miar fundamentalne, pozostawiając swoje ślady na całe życie. Chodzi tu nade wszystko o język, podstawowe wartości i normy postępowania. Kwestią zasadniczą w tym przypadku jest język. O ile bowiem pewne wartości zinternalizowane na tym etapie mogą później ulec alteracjom, o tyle język pierwotny zawsze pozostanie językiem „ojczystym”.

\subsection{Treści socjalizacji przekazywane przez rodzinę}

Holistyczny charakter rodziny jako agendy socjalizującej znajduje również swój wyraz w wielości i ważkości przekazywanych treści. Pierwsze obejmują zakresowo wszystkie elementy życia, które będą potrzebne dziecku nie tylko w rodzinie, ale i społeczeństwie. To rodzina, jako podstawowa komórka

4 É. Durkheim, Elementarne formy życia religijnego, przeł. A. Zdrożyńska, Warszawa 1990, s. 333. 
społeczna, wprowadza dziecko w świat życia społecznego - rodzi go do tej formy życia. W przeciwieństwie do biologicznego zrodzenia wprowadzanie $\mathrm{w}$ arkana życia społecznego jest rozłożone w czasie i wieloetapowe. $\mathrm{Z}$ biegiem czasu poszerza się też zakres przekazywanych treści.

Rzeczą ogromnej wagi są przekazywane przez rodzinę elementy, na których zasadza się życie społeczne: najpierw rodzinne, a następnie inne jego wymiary. Należą do nich normy moralne, wartości oraz zwyczaje. To one stanowią rdzeń każdej kultury - stylu życia każdego społeczeństwa. Dzięki nim społeczeństwo, które przechodzi głębokie zmiany ekonomiczne i polityczne, nie gubi swego pierwotnego charakteru. Charakter życia rodzinnego nacechowany głębokimi przeżyciami emocjonalnymi wiąże jednostkę z wartościami i normami, które były i są doświadczeniem w rodzinie. To „atmosfera rodzinna sprawia, że członek rodziny chętnie przyjmuje i zachowuje w swoim życiu nawet te wartości, normy i zwyczaje, które w jego oczach zatraciły już swoje uzasadnienie, a były kultywowane w rodzinie jego dzieciństwa i młodości” ${ }^{5}$.

\section{Patriotyzm jako element socjalizacji}

\subsection{Patriotyzm}

Przez patriotyzm rozumie się miłość do własnej ojczyzny. Chociaż ważnym elementem ojczyzny jest miejsce narodzin i pochodzenia, to jednak patriotyzm obejmuje znacznie szerszy zakres rzeczywistości. Ważna jest cała czasoprzestrzeń, a więc: ziemia, naród, dzieje, język, kultura, tradycje... Całość tej rzeczywistości nazwana jest często „macierzą”. Z pojęciem „ojczyzna” są zawsze związane pewne elementy prawa i władzy, ale one stają się drugorzędne. Na pierwsze miejsce wysuwają się jedność kulturowa i aksjologiczna. Na ich kanwie rodzi się więź z dużym ładunkiem uczucia - miłości, życia w ojczyźnie. Odyseusz mógł zamieszkać na pięknych wyspach z boskimi pięknościami, upajać się ich wdziękiem, ale wybrał prostą Itakę. „Owidiusz czuł się barbarzyńcą tam (na wygnaniu), gdzie ludzie nie rozumieli jego języka, gdzie kwiaty, drzewa i morze ukazywały mu jedynie swoją szarość,

5 L. Dyczewski, Rodzina polska i kierunki jej przemian, Warszawa 1981, s. 207. 
a ptaki zamiast śpiewu wydawały skrzek" ${ }^{6}$. Do miejsca swoich narodzin tęsknił nasz wieszcz Adam Mickiewicz. Pisał:

Dziś dla nas, w świecie nieproszonych gości,

W całej przeszłości i całej przyszłości

Jedna już tylko jest kraina taka,

W której jest trochę szczęścia dla Polaka:

- Kraj lat dziecięcych! (Epilog).

Cyprian Kamil Norwid tęsknił za tą wspólnotą, gdzie podnosi się kruszynę chleba, która przez nieuwagę upada na ziemię. Fryderyk Chopin w swojej muzyce zawarł powiew ojczyzny nad Sekwaną. Jednak patriotyzm „jest tylko w części uczuciem, darem natury, wynikiem samoczynnie działających mechanizmów życia narodowego. W większej mierze jest to świadoma postawa woli, wyrobione usposobienie wewnętrzne"7.

\subsection{Rodzina szkołą patriotyzmu}

Podobnie jak inne treści socjalizacyjne, również te, które dotyczą patriotyzmu, są przekazywane w dwojaki sposób: poprzez uczenie tego, czym jest patriotyzm, i przez przykład patriotycznych postaw członków rodziny, a w szczególności rodziców. W pierwszym przypadku z pomocą rodzinie przychodzą postawy etnocentryczne. Etnocentryzm jest nabytą tendencją do przedkładania nad inne własnej kultury, która jest skutkiem przebywania w określonym kręgu kulturowym. Etnocentryzmu oprócz rodziny uczą szkoła, Kościół. Ma to miejsce zawsze wtedy, gdy uczą lojalności wobec ojczyzny, historii własnego narodu czy przypominają bohaterskie czyny wielkich synów ojczyzny, i wreszcie wtedy, gdy opiewają piękno ojczystego kraju.

Jeśli jednak w odniesieniu do każdej formy socjalizacji ważniejszy od nauczania jest przykład, to w przekazywaniu postaw patriotycznych przykład własnej rodziny jest absolutnie priorytetowy. Tu w pełni ma zastosowanie zasada: Verba docent, exempla trahunt. Zwykle nie mówi się, jaką rolę spełnia ojczyzna względem jednostki, a raczej mówi się o obowiązkach jednostki względem ojczyzny. Te zaś nie są jednoznaczne we wszystkich okolicznościach. Ogólnie postawy patriotyczne streszcza powiedzenie

$6 \quad$ S. Grygiel, Pola... i sioła... to jej stopy, w: Z Karolem Wojtyłą myśląc Ojczyzna, red. W. Chudy, Lublin 2002, s. 59.

$7 \quad$ S. Olejnik, W odpowiedzi na dar i powołanie Boże, Warszawa 1979, s. 77. 
Johna Fitzgeralda Kennedy’ego „Nie pytaj, co Ameryka może zrobić dla ciebie, ale co ty możesz zrobić dla Ameryki”. W czasie pokoju najważniejszym obowiązkiem względem ojczyznay jest praca, płacenie podatków, szerzenie dobrego imienia ojczyzny. W czasie gdy ojczyźnie grozi nieprzyjaciel, obowiązkiem obywateli jest jej obrona. Przykład członków rodziny w przekazywaniu postaw patriotycznych jest oczywisty. Nawiązała do niego w swojej balladzie Anna Fischerówna, która włożyła w usta młodego obrońcy Lwowa, 15-letniego Jurka Bitschana, następujące słowa:

Mamo najdroższa bądź zdrowa.

Do braci idę w bój.

Twoje uczyły mnie słowa.

Nauczał przykład Twój.

Rodzina staje się szkołą patriotyzmu przez swój charakter i funkcjonowanie. Rodzina jest grupą podstawową, pierwotną ze wszystkimi jej cechami. Jako najbliższe i jedyne w swoim rodzaju środowisko staje się szkołą cnót, które są pożądane nie tylko w rodzinie, ale i w ojczyźnie. Najważniejsza jest zdolność poświęcania się na rzecz rodziny. Ta cecha, potrzebna rodzinie do tego stopnia, że bez niej rodzina ulega dezintegracji, staje się ogromnie potrzebna w relacji jednostka-ojczyzna. Trudno sobie wyobrazić sytuację, by członek rodziny był zdolny do poświęcania się dla ojczyzny, jeśli nie jest w stanie poświęcać się dla rodziny.

Ważnym wymiarem patriotycznej socjalizacji w rodzinie jest kultywowanie przez nią rodzimych zwyczajów. Te bowiem stanowią konstytutywny element kultury ojczystej. Ich pielęgnowanie zabezpiecza przed kulturową dezintegracją. Ma to miejsce nawet wtedy, gdy pielęgnowane zwyczaje zmieniają ich pierwotny sens. Nawet w takim przypadku są wyrazem kontynuacji kultury narodowej. W tej sytuacji rodzina „pełni [...] rolę swoistego rodzaju pomostu pomiędzy «dawnymi i nowymi laty» oraz pomiędzy jednostką i narodem. Przez to zaś, że pielęgnowane w niej zwyczaje przeżywane są bardzo indywidualnie, w niewielkiej grupie osób, z dużym ładunkiem emocjonalnym, zakorzeniają one jednostkę głęboko w to wszystko, co nazywamy dziedzictwem kulturowym i rodziny i narodu"8.

Kultura rodzinnej grupy przez swój holistyczny charakter staje się czymś w rodzaju symbolicznego uniwersum, w którym wszystko ma swoje od-

8 L. Dyczewski, Rodzina, społeczeństwo, państwo, Lublin 1994, s. 116. 
zwierciedlenie. To symboliczne uniwersum „wyznacza im wartości i normy, kształtuje ich widzenie siebie i świata, reakcje uczuciowe i zachowania, oceny przeszłości i wizje przyszłości, formy tworzenia i sposoby użytkowania wzorów kulturowych. Pobudza ich do zadawania pytań o sens życia jednostkowego i społecznego"'. Ojczyzna, jej kondycja i jej funkcjonowanie są przedmiotem szczególnej uwagi.

\section{Aberracje patriotyzmu}

Aberracje w kontekście patriotyzmu idą zasadniczo w dwóch kierunkach: kosmopolityzmu i nacjonalizmu.

\subsection{Kosmopolityzm}

Kosmopolityzm jest zanikiem patriotycznych postaw. Ich miejsce zajmują postawy ukierunkowane na świat jako całość. Cały świat i każda jego część są „ojczyzną". Sednem kosmopolityzmu jest zasada Ubi bene, ibi patria. Dla zwolenników kosmopolityzmu znika pojęcie ojczyzny narodowej, a staje się nią cały świat. „Obywatel” państwa narodowego staje się bardziej obywatelem świata niż własnego państwa.

Zwolennicy kosmopolityzmu różnych odcieni pojawiali się na przestrzeni wieków od filozofii greckiej aż po obecne czasy. Seneka Młodszy w liście do Lucyliusza pisał, że jego ojczyzną jest cały świat. Marek Aureliusz uważał, że jego ojczyzną jako Marka Aureliusza jest Rzym, podczas gdy jako człowieka jest świat ${ }^{10}$. Zwolennikami kosmopolityzmu byli przedstawiciele oświecenia: Voltaire, Rousseau... Współcześnie idee kosmopolityzmu są bliskie globalistom.

Swoistym wyrazem kosmopolityzmu, mieszczącym się w zasadzie: $u b i$ bene, ibi patria, jest obecna polska emigracja. Emigracja ze swej istoty nie jest wyrazem braku patriotycznych postaw, wręcz przeciwnie, niekiedy jest ich wyrazem. Podobnie nie była apatriotyczna emigracja zarobkowa z Galicji XIX wieku, ponieważ chroniła emigrantów i ich rodziny przed nędzą, a nawet śmiercią. Podobnie nie była wyrazem braku patriotycznych postaw emigracja polityczna po upadku powstania listopadowego w 1831 roku czy

\footnotetext{
$9 \quad$ L. Dyczewski, Kultura polska w procesie przemian, Lublin 1993, s. 40.

10 M. Aureliusz, Rozmyślania, tłum. M. Reiter, 6.44, Warszawa 1937.
} 
pozostanie na emigracji zdemobilizowanych polskich żołnierzy po II wojnie światowej. Pierwsi w najlepszym wypadku skończyliby na Syberii jako zesłańcy lub w obozach przymusowej pracy; drudzy -torturowani w ubeckich więzieniach. Pomimo tego miał sobie do wyrzucenia udanie się na emigrację nasz wieszcz Adam Mickiewicz. Pisał:

Biada nam, zbiegi, żeśmy w czas morowy,

Lękliwe nieśli za granicę głowy! (Epilog)

O ile pewnym usprawiedliwieniem dla emigracji zarobkowej Polaków $\mathrm{w}$ okresie transformacji systemowej było wysokie bezrobocie, o tyle obecnie już tak nie jest. Obecnie w Polsce jest pracy pod dostatkiem, a wręcz brakuje pracowników. Stąd emigracja, zwłaszcza całej rodziny na stałe, jako sposób na bardziej wygodne życie jest postawą na wskroś kosmopolityczną. W niektórych przypadkach wręcz nabiera charakteru wątpliwej moralności. I tak, jeśli po zdobyciu wyższego wykształcenia na koszt polskich podatników ktoś wyjeżdża do pracy do państwa o wyższym standardzie życia, okrada własne państwo. Gdyby do tego dodać fakt, że emigrujące młode małżeństwa rodzą dzieci dla "nowej ojczyzny”, a nie dla prawdziwej ojczyzny, to sytuacja jest jeszcze bardziej daleka od postaw patriotycznych. Dzieci urodzone w „nowej ojczyźnie” nigdy nie powrócą do kraju pochodzenia rodziców.

Specyficzną formą kosmopolityzmu jest ideologia komunistycznego internacjonalizmu. W jej ramach proletariusze wszystkich krajów łączą się $\mathrm{w}$ walce przeciwko systemowi kapitalistycznemu celem stworzenia wolnej od wyzysku i konfliktu wspólnoty. W swej istocie komunistyczny internacjonalizm jest ideologią „sztuczną”, pozbawioną trwałej bazy, odniesienia do wartości.

\subsection{Nacjonalizm}

Nacjonalizm, wywodzący się od słowa natio - naród, jest doktryną społeczno-polityczną, w której w centralną pozycję zajmuje naród. Naród też zajmuje najwyższą pozycję w systemie wartości, której podporządkowane są wszystkie inne, łącznie z wartościami religijnymi. Sama zaś religia staje się religią narodową ${ }^{11}$. Nacjonalizm zwykle rodzi się w sytuacji, kiedy zani-

11 Do tej sytuacji odniósł się w swojej encyklice Mit brennender Sorge papież Pius XI, pisząc: „Kto wynosi ponad skalę wartości ziemskich rasę lub naród, albo państwo, albo ustrój państwa, przedstawicieli władzy państwowej albo inne podstawowe wartości ludzkiej społeczności, które w porządku doczesnym zajmują istotne i czcigodne miejsce, i czyni z nich 
kają więzy o charakterze naturalnym, wspólnotowym. Ich miejsce zajmuje doktryna oparta na więzi narodowej. Początki takiej doktryny związane są $\mathrm{z}$ reformacją. W nauczaniu Marcina Lutra prawo państwowe - prawo pozytywne nie ma swego odniesienia do prawa wyższego rzędu o charakterze uniwersalistycznym. Jego źródłem jest państwo. Ono samo nie podlega moralnemu osądowi. Nierzadko sama doktryna o charakterze nacjonalistycznym znajduje swoje dopełnienie w systemie politycznym. Państwo bazujące na takiej doktrynie jest wrogo nastawione do innych narodów, a niekiedy nawet dąży do ich eksterminacji. Zwrócił na to niebezpieczeństwo uwagę papież Pius XII w encyklice Summi Pontificatus. „Ideologia przypisująca państwu władzę prawie nieograniczoną staje się błędem zgubnym nie tylko dla wewnętrznego życia narodów, dla ich dobrobytu i moralnego rozwoju, ale szkodzi także wzajemnym stosunkom narodów, gdyż rozrywa łączność, jaka powinna istnieć między państwami, pozbawia siły i trwałości prawo narodów, otwiera drogę do gwałcenia praw drugiego i utrudnia wszelkie porozumienie i pokojowe współżycie" (SP 58).

\subsection{Postmodernizm}

Specyficzną kategorię postaw względem ojczyzny prezentują zwolennicy filozofii postmodernistycznej. Postawy te wyrastają w kontekście totalnego kryzysu najpierw epistemologicznego, a następnie kryzysu wartości. W ramach tej filozofii nie istnieje prawda obiektywna. „Prawda” jest kreowana w procesie poznania. Oznacza to, że tyle jest „prawd”, ile podmiotów poznających. Podobnie jak nie ma jednej prawdy, również nie ma wartości niższych i wyższych. Świat aksjologiczny jest sterylny. Stąd cokolwiek człowiek stara się czynić, jakiekolwiek odnosiłby sukcesy, nie ma żadnego znaczenia; świat jego działań przebiega poza wymiarem wartości. Skoro nie ma żadnych wartości, to tym bardziej nie ma wartości, dla których warto żyć i za które warto poświęcić życie. Człowiek funkcjonuje w aksjologicznej pustce. Jego świat jest aksjologicznie sterylny ${ }^{12}$. Wprawdzie „wyznawcy tego nurtu

najwyższą normę wszystkich wartości, także religijnych, i oddaje im cześć bałwochwalczą, ten przewraca i fałszuje porządek rzeczy, stworzony i ustanowiony przez Boga Człowieka, i daleki jest od prawdziwej wiary w Boga i od światopoglądu odpowiadającego takiej wierze" (MBS 12).

12 Jedyną „wartością" dla postmodernisty jest wolność, która pozwala mu funkcjonować poza złem i dobrem. Zob. A. Bronk, Krajobraz postmodernistyczny, „Ethos” 33-34 (1996), s. 95. 
mają oczy, ale nie widzą, poruszają się w świecie wartości, ale niczego nie pragną"13.

Filozofia ponowoczesnego społeczeństwa to filozofia kultury zindywidualizowanej. Postmodernista nie dostrzega wokół siebie ani poza sobą żadnego ładu, który mógłby go inspirować i stanowić dla niego punkt zaczepienia. Wszystko, co człowieka otacza, jest przypadkowym aglomeratem rzeczy. Jednostka jest samotną wyspą na wodach niezmierzonego oceanu. W swym osamotnieniu nie może na nikogo liczyć, nikomu też nie jest potrzebna! Ta totalna nędza człowieka czyni go niezdolnym do jakiegokolwiek wysiłku dla innych. Tym bardziej dobro ojczyzny wymyka się z pola jego widzenia i zainteresowania postmodernisty.

\section{Zakończenie}

Jednostka, rodząc się, zostaje przypisana do określonej grupy, grupy rodzinnej, ale też do kręgu kulturowego swoich rodziców. Fakt ten nie czyni z dziecka automatycznie uczestnika tej kultury, na wzór tego, co ma miejsce w wymiarze biologicznym, cielesnym. „Rodzenie” do życia społecznego przyjmuje postać długiego procesu, w który zaangażowane są różne agendy socjalizujące. Rodzina jest pierwszą z nich i najważniejszą. Wynika to tak $\mathrm{z}$ charakteru samej rodziny, jak i z chronologicznego usytuowania jej w procesie socjalizacji.

Wśród treści, jakie są internalizowane w ramach procesu socjalizacji przez rodzinę, jest też patriotyzm. Wprawdzie postawy patriotyczne mogą być wzmacniane przez inne agendy socjalizujące, a w szczególności szkołę i Kościół, jednak rodzina jest najlepszą i najskuteczniejszą szkołą patriotyzmu. I tak, ucząc dziecko ojczystego języka, przekazując normy, zwyczaje, przekazuje się dziecku zręby kultury narodowej, w której zwykle będzie się poruszało przez całe życie. Ten styl funkcjonowania stanie się na całe jego życie niezastępowalnym, nawet jeśli losy rzucą go w odmienne od rodzinnego środowisko.

Wreszcie, skoro patriotyzm to nie tylko emocjonalne nastawienie do wartości własnej kultury, ale umiejętność poświęcania się dla ojczyzny, to

13 W. Majkowski, Od sekularyzacji do sekularyzmu, w: Człowiek i społeczeństwo w dobie przemian, red. A. Wołk, Warszawa 2005, s. 130. 
rodzina nie ma równego sobie środowiska w szkole altruizmu. To w rodzinie dziecko uczy się szacunku dla rodziców, na miarę swoich możliwości im pomaga, uczy się współżycia z innymi członkami rodziny, solidarności grupy rodzinnej... Można pokusić się o stwierdzenie, że bez tego etapu przekazywania postaw patriotycznych jednostka nigdy nie stanie się w pełni patriotą.

\section{Bibliografia}

Aureliusz M., Rozmyślania, tłum. M. Reiter, Warszawa 1937.

Bronk A., Krajobraz postmodernistyczny, „Ethos” 33-34 (1996), s. 79-100.

Cichoń W., Wartości, człowiek, wychowanie, Kraków 1996.

Durkheim É., Elementarne formy życia religijnego, przeł. A. Zdrożyńska, Warszawa 1990.

Dyczewski L., Rodzina polska i kierunki jej przemian, Warszawa 1981.

Dyczewski L., Kultura polska w procesie przemian, Lublin 1993.

Dyczewski L., Kultura, społeczeństwo, państwo, Lublin 1994.

Grygiel S., Pola... i sioła... to jej stopy, w: Z Karolem Wojtyła myślac Ojczy$z n a$, red. W. Chudy, Lublin 2002, s. 57-73.

Majkowski W., Od sekularyzacji do sekularyzmu, w: Człowiek i społeczeństwo w dobie przemian, red. A. Wołk, Warszawa 2005, s. 118-130.

Olejnik S., W odpowiedzi na dar i powołanie Boże, Warszawa 1979.

Pius XI, Mit brennender Sorge, Roma 1937.

Pius XII, Summi Pontificatus, Roma 1939.

Siemianowski A., Człowiek a świat wartości, Warszawa 1993.

Sobór Watykański II, Gravissimum educationis, Roma 1965. 
